\title{
Migration Perspectives in Social Work Research: Local, National and International Contexts
}

\author{
Pat Cox ${ }^{1, *}$ and Thomas Geisen ${ }^{2}$
}

\author{
${ }^{1}$ School of Social Work, University of Central Lancashire, Preston, PR1 2HE, UK \\ ${ }^{2}$ School of Social Work, Institute for Integration and Participation, University of Applied Sciences \\ Northwestern Switzerland, Riggenbachstrasse 16, 4600 Olten, Switzerland \\ *Correspondence to Pat Cox, Reader in Social Work and Social Justice, School of Social Work, \\ University of Central Lancashire, Preston, PR12HE, UK. E-mail: pcox2@uclan.ac.uk
}

\begin{abstract}
Within social work, it is often assumed that migration is a signifier for social deprivation; however, closer examination of migrant populations in different European countries reveals tremendous heterogeneity. For example, recent migration patterns in Germany, Switzerland and the UK show that inward migration is characterised also by highly qualified migrant peoples. Against this background, the question arises as to what are the relevant issues which make migration a question for social work and what subjects should be addressed in social work research? This paper begins with conceptual considerations on the complexity of migration. Examining examples of social work research into migration, children and young people in the English and German languages from a cross-national systematic review, undertaken by the authors and spanning 2000-13, the authors identify the main foci of social work migration research thus far. Findings from the selected studies demonstrate a paucity and generality of social work research into migration and that the predominant focus is migration as a challenge for certain groups of migrant peoples, such as people seeking refuge or asylum. The authors argue that changes to practices in social work migration research, incorporating local, regional and international perspectives, are needed.
\end{abstract}

Keywords: Migration, social work research, marginalisation, international research, children and young people, complexity

Accepted: April 2014 


\section{Introduction}

Despite migration being a complex and multidimensional global, national and local phenomenon - a practice inherent in modern societies and nations there is little acknowledgement in social work that existing societies and nations already are dynamic in their composition, having been transformed by and being comprised of the descendants of earlier-arriving migrant peoples (Cox, 2014a; Geisen et al., 2013; Portes and DeWind, 2008), and only limited recognition that social work practitioners, educators, researchers, carers and service users and students (and by no means are these exclusive groupings) are also migrant peoples or are their descendants (Fouché et al., 2013). Migration is, however, inextricably intertwined with issues which are the business of social work: democracy and citizenship rights; law and policy; education, health, social relations and the interconnections of all these issues with one another. Modern societies can be described as migration societies (Geisen, 2010) and the challenge for social work therefore is how to respond to issues arising for migrant peoples and their movements, both internal and international, in addition to issues for nations, societies and communities, due to the fact that migration challenges and changes established social relations for groups in each and all of these contexts.

We begin by exploring conceptual issues and migration as a human condition, noting the significance of marginalisation for social work research into migration. We address the role played by nation states in structuring migration, analysing how they prolong clear distinctions between settled peoples and newcomers, and how this impacts upon thinking in social work migration research. We briefly examine migration in social work theory, practice and research. Drawing from the findings of studies in the systematic review, we discuss the implications for social work research. Social work migration research can contribute to improving practice and we distinguish between studies with a wide or specific focus, arguing that social work migration research needs to incorporate local, regional and international perspectives.

\section{Conceptual issues and migration as a human condition}

Migration includes wide-ranging experiences of peoples of different races, nationalities, ethnicities, and social and cultural backgrounds, with different migration patterns (including extensive temporary migration) occurring across time. Although it is not universally acknowledged, migration has been and is integral to human experience, encompassing both human flourishing and human suffering (Harzig and Hoerder, 2009). Forced migration and resettlement - refugees created by war, civil war and genocide (Davidson, 2012) - and development-induced displacement are other significant migratory patterns (Beine and Parsons, 2013; de Wet, 2006). Also included are the 
manifold aspects of migration processes and settlement in new nations, societies and communities, especially with regard to their potential impact on social and political developments (Geisen, 2004; Kofman et al., 2011). Because it is a complex challenge for modern societies, migration can be perceived as the emblematic condition of this age (Castles and Miller, 2009).

That migration is not predominantly from the global south to the global north-one-third of migrant peoples relocate between global south nations and in many nations internal migration movements are as great as (or greater than) those from elsewhere (Bastia, 2013) - is not widely recognised. The most common implicit or explicit understanding of migration is as international migration; however, in addition to international migrant peoples, internal migrant peoples move within nation states; between regions or cities; into urban settings from rural areas or the reverse. Although these two modes of migration generally are considered different in their social, cultural and economic relevance, many migratory experiences are shared equally by both international and internal migrant peoples. Page Moch (1997) defines migration as:

$\ldots$ a change in residence beyond a communal boundary ... migration includes
moves from one village to another as well as those across national borders and
oceans. Temporally, migration may be short-term or permanent... such an
inclusive view of geographical mobility recognises the interconnections
among regional, national, international, and transoceanic migrations and
the necessity of considering them as a whole (Page Moch, 1997, p. 43).

Nation states now perceive migration as an urgent problem which can no longer be ignored or circumvented (Benhabib, 2004; Geisen, 2004), with implications for governance and citizenship. Difficulties are experienced in integrating new members and, in many nation states in the global north, migrant peoples frequently are characterised as existential threats (de Haas, 2008; Huysmans, 2005), rather than as people wanting to integrate themselves into new surroundings. Extreme nationalism (Rydgren, 2003; Wodak and Van Dijk, 2000) and other forms of prejudice engender negativity and hate crimes against migrant peoples. Distinctions often are made between highly qualified ('expatriates') and less-qualified migrant peoples. Almost everywhere, indigenous peoples are seen as the social norm and migrant peoples as exceptions, leading to social, cultural and political practices that draw fundamental lines of difference between people already established in a country or region and the newcomers (Benhabib et al., 2007).

The widespread construction of belonging by citizenship in the nation state obscures the fact that much migration is internal (Page Moch, 1997; Office for National Statistics, 2011,2013). It leads to erroneous assumptions that migration is about the recent arrival of 'outsiders' - an issue to be managed, rather than a continuous human practice and near-universal human experience (Castles and Miller, 2009; Kasinitz et al., 2008). Because each nation state formulates policy, legal and social responses to inward or internal migration 
according to its perceived requirements, much existing research into migration is driven by national politics (Bakewell, 2008). Research is therefore limited by being oriented towards the interests of nation states in migration, predominantly focusing on the experiences and activities of migrant peoples in their receiving nations (Kalter, 2008); transnational thinking in migration research is a comparatively recent development (Parnreiter, 2000).

\section{Migration as a concept in social work theory and research}

Currently in social work theory, the concept of migration is not widely explored. Migration is usually included in social work education and practice as an issue of particular needs, such as support for refugee migrant peoples or in relation to family (re)unification (Treichler and Cyrus, 2004). Elliott and Segal $(2012$, p. 564) write that 'social workers need to understand the context of their clients' experience, as well as the complexity of world politics and economics that influence the way governments of nation-states formulate immigration policies'. However, the term 'migration' often is deployed without clarifying its meaning and migration's intersections with social dimensions such as 'race', ethnicities, gender, sexuality, age and class backgrounds (Crenshaw, 1991; Collins, 1990) frequently are not clarified. For example, who wants to be known as or call themself a migrant person and who does not want to be known thus (Newcomers? Second-generation members? Later-generation members? Highly qualified or less-qualified migrant workers, or both?). Which generations are still referred to as migrant peoples, even if they themselves did not migrate?

As noted above, the dominant (and inaccurate) construction within social work of migration focuses upon migrant peoples crossing national borders, making new lives. It elides the experiences which 'internal migrant peoples' (Geisen, 2005; Office for National Statistics, 2011, 2013) share with international migrant peoples. It elides also the experiences of second, third and later generations (Cox, 2014a; Karpf, 1996; Kasinitz et al., 2008). It disregards how improved technologies and travel facilitate migrant peoples retaining close ties with families and friends in countries or regions of origin; new lives are being developed and existing relationships are maintained (Geisen et al., 2013, 2014; Parnreiter, 2000). Page Moch's (1997) inclusive definition overcomes the limitations of the prevailing construction and, for social work, opens up consideration of the manifold migratory experiences of both settled and newly arriving groups.

For established and indigenous peoples, migration often leads to their being confronted by perceived 'differences' of migrant peoples, resulting in perceived (our emphasis) greater competition in labour markets, for housing, education or social benefits (Clarke and Garner, 2005). Additional challenges are the imperative for communities, societies and nations to develop social practices of welcoming and participation, as well as having 
rights to maintain distance. Established social relations in communities, societies and nations are changed or relinquished and, in the new settings, social relations must be established anew (Valtonen, 2008). Both established groups and newcomers need to learn how to respond to change and multiple differences in everyday life. When newcomers (internal or international) participate in social and community life in receiving societies, their participation impacts local residents' lives. Such processes and practices include social, political and cultural transformations, and continuities for community life within the new places of settlement, as well as the old. The 'lived experience' of these processes for both groups influences both the dynamics of belonging and established relations of power and dominance (Valtonen, 2001, 2002). There is no 'outside' of a society; everyone who lives in a society is always a part of it, because changes in a society influence individual and collective social practices (Geisen, 2010). Thus, migration is a core business of social work, because social workers engage with individuals, families and groups and with their social relationships within their wider networks of communities, societies and nations (our emphasis).

Since the beginning of the twenty-first century, 'integration' of migrant peoples within nation states, societies and communities has become more prominent in social work, leading to greater emphasis on mainstreaming migration through addressing cross-cultural practices and competences (Hamburger, 2009). Structural issues of power and oppression, including racism, are experienced by both international and internal migrant peoples (Hickey, 2011; Lentin, 2008), and race oppression intersects with dimensions such as class or nationality (Balibar and Wallerstein, 1991). Oppressive and exclusionary attitudes and behaviours impact upon all migrant peoples, influencing self-confidence; self-esteem and self-worth at intra-personal, interpersonal, institutional and macro-political levels (Cox, 2014b; Marvakis, 2011), linking integration, marginalisation and social exclusion-all matters of concern for social work.

The proposed International Definition of Social Work (International Federation of Social Workers and International Association of Schools of Social Work, hereafter IFSW and IASSW, 2013) emphasises 'social cohesion ... the empowerment and liberation of people. Principles of social justice, human rights, collective responsibility and respect for diversities are central to social work'. This definition resonates with current thinking (Ife, 2008) about social work as human rights practice. Social work, undertaken at the intersections of personal, social justice and political issues in everyday life (Salomon, 1997), is well placed to understand and support migrant people's engagement with complex emotions, experiences, in their loss of and rebuilding social relationships, to work with them to challenge marginalisation, oppression and exclusion, and to achieve recognition of their human rights and rights to social justice. For the combined issues of migration and social work, human rights and social justice are paramount (Humphries, 2008). 


\section{Limitations and challenges in social work research and migration}

Social work research which addresses the implications of migration for social work practice and social work education (Valtonen, 2001,2008; Williams and Graham, 2012)-issues which are of local, national and international concern - has developed slowly in recent years and remains limited. Given the increasing emphasis on social work as a world endeavour (e.g. Bender et al., 2013; IFSW and IASSW, 2013; Reutlinger et al., 2008), this apparent lack of social work research attention to migration issues, a key factor in local and global processes, is astonishing. In addition, very few international comparative studies exist: work by Dettlaff et al. (2009) is an exception to this. Elliott and Segal (2012, p. 576) argue that 'Social work needs to focus on research in the field (migration) if the profession is to participate in policy making and ensure improvement of services to clients who are migrants'. However, there is no detailed discussion of what kinds of social work research might be needed. Segal and Heck (2012, p. 112) do not discuss the relevance of social work research concerning migration; nor do they reference existing social work migration research. They assert that 'social work academia has been even slower' in recognising the impact of migration and this assertion is echoed by Alam (2013) (see the 'Discussion' section).

Migration movements challenge normative concepts of regions and nation states: Who is accepted here? Who has citizenship rights? How are individuals, families and communities connected before, during and after migration? How are they disrupted and remade during and following migration? How are migrant individuals, families and communities affected by racism, xenophobia and hatred, and why is there no unified response to such personal and institutional hostility from the social work profession (Spalek and McDonald, 2011). These questions and many others open up possibilities for social work research to engage critically with migration experiences, which are simultaneously individual, societal, national and international. From all of the foregoing, it is clear that the social world is being transformed by migration and social work is playing catch-up. To address these questions and their implication for social work research, we now examine findings from studies in the review of social work research into migration, children and young people (2000-13) in English and German, identifying both wide and specific understandings and foci, key issues and themes. Some studies address more than one issue.

\section{Examples of social work migration studies with a wide understanding and focus}

There are a number of studies focusing on experiences of refugee, undocumented and asylum-seeking or trafficked children and young people and 
those who travel unaccompanied. Examples include Maegusuku-Hewett et al. (2007), Pearce (2011) and Warwick et al. (2006), all conveying the complex emotional issues which children and young people in these situations experience and the importance for services to be responsive to need. In addition, Pearce's study differentiates between the needs of younger and older children.

Families feature in many studies of children and young people's migration. Alaggia et al. (2001) examine young people's own perspectives of how migration affects family structures and relationships; Michael (2009) focuses on relationship issues for young women in migrant families. Renzaho and colleagues' (2010) research with African families who have migrated to Australia develop detailed understandings of the families' lives through focus group discussions; the authors argue that social and cultural issues impact on many intergenerational concerns. The effects of the separation of children and parents in transnational families, particularly for the children, are examined in a recent study (Geisen, 2014).

Studies which target groups of young migrant peoples often address health issues. Research by Choo and Sim (2010) and by Torres et al. (2008) exemplify similar work, examining health risks which young migrant peoples may be exposed to, as they move into receiving societies and emphasising the importance of local and other knowledges in professionals' responses.

'Life strategies' is a recurring theme in many studies. One such is a mixedmethods study by Sauer and Held (2006) with school-aged children aged between nine and fourteen-some from migrant families and some from indigenous families - in south-western Germany and California. The authors identify this age group as under-researched in exploring integration (another theme in this study), culture and friendship. The mixed-methods design facilitated analysis of a range of issues for both groups of children in both countries, which the authors assert has implications for professional practice.

Identity, diversity and belonging combine to form another significant theme-or series of interlinked themes. Adjusting to new surroundings and different expectations in receiving societies is addressed by Alt (2012), comparing the experiences of migrant families of differing nationalities with those of German families and demonstrating the capabilities and resilience of young migrant peoples and their parents building new lives. Studying secondgeneration migrant peoples and how they create identities and become acculturated into their receiving society, Alam (2013) gathers the experiences of both young women and young men. Comparisons among and between indigenous young people aged fifteen in Germany and England and young Turkish people in both countries are the subjects of a study by Faas (2009). Having used qualitative methods, data analysis demonstrated the young people had no singular identity, but a complex bricolage of hybrid identities, with both education and class backgrounds having significant influence.

Issues of culture and of 'race' may be deployed against migrant children and young peoples by other groups. Leiprecht's (2001) study of racism and 
young people in Germany and in the Netherlands and Jacob's (2011) work on the meaning of Islam for Turkish young people living in Germany address the vulnerabilities which young migrant peoples' experience in relation to their 'race', culture or religion.

\section{Examples of social work migration studies with a specific understanding and focus}

Studies of fostering migrant children include those by Bates et al. (2005), Sirriyeh (2013) and one by Von Langsdorff (2012), exploring with young migrant women in foster-care the relevance of different intersectional dimensions in their biographies.

Concerning service provision, Riedi and Haab (2007) examine how young people from the Balkans can be supported to integrate into Swiss society and the issues which the young people and workers in support services experience in this process. Morantz et al. (2013) explore refugee families' lack of access to childcare, comparing their situations with those of indigenous families elsewhere in Canada and Europe, arguing that refugee families' care needs should be considered when designing services. Research addressing the responses of workers to young migrant people's situations includes studies by Dunkerley et al. (2005), Martin et al. (2011), Okitikpi and Aymer (2003) and Wade et al.'s (2005) longitudinal study of three social service departments. Recent research with young migrant people in foster-care (Schaffner et al., 2014) demonstrates that social workers had difficulties responding to the young people's migration issues.

\section{Discussion}

Our searches in both languages revealed many relevant migration studies in health, psychology, psychotherapy, education and medicine, and in the social and political sciences, which social work can learn from and apply. We found far fewer social work migration studies: as Alam (2013, pp. 646-7) notes, social work migration research 'has yet to develop parity with sister disciplines, let alone carve out a domain-specific vantage point'. While it can be argued that the topics of families, life strategies, culture and identity/diversity/belonging and health are research subjects for other social science disciplines too, and that this is also true for the topics of refugee, undocumented and asylum-seeking children and young people and young migrant people's experiences of racism, they are also research topics for social work, as is the provision of social work, welfare or care services.

The studies reflect much which has been noted above. For example, the emphasis is on international migration as the primary movement, with associated 
elision of internal migratory movements and shared experiences. There is a lack of continuity in empirical research in social work's practice areas. There is a focus on refugee and asylum-seeking children and young people, rather than all groups of young migrant people. The impact of trauma, engendered by persecution in nations of origin is central to a number of studies with refugee and asylum-seeking children and young people. It is essential that the short and long-term impacts of trauma are understood and acknowledged: however, this may inadvertently deny children and young people's agency and resilience (Chase, 2010). Migration researchers Anderman (2002), Westoby and Ingamells (2010) and Zack-Williams (2006) argue that current constructions of trauma and its impacts are from the perspectives of global north nations and that what counts as trauma is for migrant peoples themselves to define.

Little attention is paid to the role of nation states, societies and communities, and rarely is there any interrogation of the part played by the global north nations. Frequently, the 'new knowledge' being sought relates to national, rather than international, contexts. In many studies, an overarching, all-encompassing issue is being researched in its application to a particular area or areas of practice, instead of being understood and analysed as a human experience. Bakewell (2008) notes that much migration research treats migrant peoples as exceptions, rather than emphasising the normality of their situation; but, as noted above, migration can no longer be understood as exceptional practices undertaken by 'exceptional others'. Nevertheless, many of the studies adopt this perspective and some studies risk incurring the epithets of 'sociological sentimentality' or 'advocacy' research which 'displays' marginalised groups (Gouldner, 1973), such as migrant peoples. These studies show what has been achieved to date in social work migration research; however, Masocha's (2013) recent work reveals social workers' lack of knowledge about migration issues and consequent uncertainty in interventions with adult asylum-seeking peoples. More social work migration research and, we argue, a different kind of social work migration research is needed. Next, we examine how to take forward the ideas about migration research discussed here.

The definition of social work proposed by IFSW and IASSW (2013) provides the profession with a mandate to strive for human rights, social justice and empowerment of peoples. Valtonen (2001, 2002, 2008) extrapolates from her research with adult migrant peoples' relevant learnings for anti-oppressive practice, underpinned by principles of social justice in social work with migrant peoples and their communities. Just as social work must centralise social justice, social work research must do likewise (Humphries, 2008), starting with developing new practices in social work migration research.

What could social work research into migration look like? First, it is necessary to de-centre existing social work research practices: instead of practices of 'adding in...' (migration to research), or 'bolting (migration) onto...' 
(existing research specialisms), practices must be reconfigured. In order that the everyday, the normal and the shared internal and international migratory experiences are the focus, not the 'exceptionality', a fundamental requirement is that migrant peoples - young people and children, internal and international, newly arrived and their descendants-should decide their own research questions, design and undertake studies (Pitts and Smith, 2007). Little research attention is paid to the generative and regenerative outcomes of migration for receiving societies and nations; migrant peoples' contributions to social life, politics, culture and communities are often disregarded (Nguyen, 2005; Portes and Yiu, 2013). Marvakis (2011) asserts migrant peoples' subjectivity and agency despite marginalisation; migrant peoples are well placed to record the impact of their own migratory experiences; they must be subjects of their own lives and research, not the object of others' research.

Research is needed which focuses on contexts and processes of migration by taking a diachronic and synchronic perspective, exploring the migration trajectories and life strategies of individuals, families and groups in networks, communities and societies (Valtonen, 2008). This includes the reconstruction of biographies and both memories and narratives of experience of movement and remaking, which are contextualised within the development of migration policies and practices - '... a fluid bricolage' (Raasch, 2012, p. 80)-and which facilitate social change (Cox et al., 2008). With migrant peoples of all ages designing and leading their own research, there will be no 'sociological sentimentality' (Gouldner, 1973). Such research should address conditions of marginalisation, including racism, poverty and exclusion, which limit possibilities for social participation. As Fals-Borda and Rahman (1991) note, participatory action research transcends existing knowledge monopolies to produce research which leads to action. Social work research needs to reconnect with participatory research frameworks and community-based research (Green, 2008), with social work researchers and practitioners supporting migrant peoples to develop their own questions of interest to them, if support is requested. Such research will be grounded in particular ethical principles, rather than in general ones (Hugman et al., 2011; Humphries, 2008).

Currently in social work research, national myopia often prevails. Social work research into migration must avoid 'methodological nationalism' (Glick Schiller and Wimmer, 2002) and find ways to circumvent successfully the existing boundaries of 'race', ethnicity, culture and class which may limit understanding, while not minimising their significance. Because there is no unitary method deployed by nation states or NGOs to record inward migration, some of which is illegal and unrecorded, international research is sometimes considered to be problematic. Moving beyond exhortations about the 'global', international social work research, including migration 'within', as well as 'between', and which eschews relativist approaches (Mohanty, 2003 ) is essential. Individual nation-state-based social work migration research, which is driven by hegemonic domestic structural and political forces, is limited, as already noted. International studies of migration in 
social sciences show what is possible (Bloemraad, 2013; Liamputtong, 2010), despite difficulties encountered (Liamputtong, 2008) and social work research can learn from these. New thinking leads to new knowledge, moving beyond Westphalian thinking and recognising opportunities to change 'what is' to 'what could be' (Calhoun, 2000, p. 511).

With this in mind, it is the responsibility of social work researchers to press for more international social work research with and in organisations working with and on behalf of migrant peoples and campaigning for improved conditions. NGOs are one such set of organisations and social work researchers must engage in 'dialogical relationships' with migrant peoples (Leonard, 1997), and with NGOs, working together to construct alternative knowledges which are international in scope, whilst retaining a sense of the local, regional and the national (Alam, 2013; Williams and Guémar, 2008). Cross-regional migration also must be significant in the social work migration research endeavour, undertaken in tandem with international studies (Page Moch, 1997); this, too, is a responsibility for social work researchers.

\section{Conclusion}

As demonstrated above from findings of studies in the literature review, existing social work research into migration has contributed towards understanding the life-worlds of migrant peoples. However, it is still necessary to supersede the frequently found traditional nation-state-based distinction between international and internal migration. Social work research must engage in bridging this distinction by examining the general relevance of leaving somewhere and becoming a newcomer elsewhere, focusing on both internal and international migrant peoples. Both a wide and a specific focus in social work research is necessary. Under the wider perspective, there is an imperative to engage in research with migrant peoples living under conditions of marginalisation. In relation to the specific perspective, there is a need for much more social work research than has been undertaken to date.

For social work, the complexity of migration under conditions of marginalisation would be a new paradigm for thinking about and undertaking migration research-a paradigm which transcends existing limitations in social work research, focusing on the coherence of social relations by referring to the interconnectedness of the local, the national and the international. There is a pressing need for larger numbers of comparative international social work studies, seeking more nuanced understandings of social relations, social conditions and social differences between countries. Such studies would provide possibilities for international dialogue, contributing to internationally grounded knowledge on the subject of migration. The complexity of migration is such that, as outlined above, migration alters everything for everyone. 
It is important to acknowledge here that devolvement of accountability to individuals, together with concrete realities in organisations and responsibilisation in many nation states (Rose, 1998), reinforces both disciplinary and nation-state mentalities, making the changes we propose appear impossible to achieve. However, changing research practices in the interests of social justice must be constant and consistent (Wright, 2010): viable, achievable alternatives to current research can be attained.

Social work research is being undertaken in 'a world on the move', during the 'age of migration' (Castles and Miller, 2009), and social work research on migration could contribute to wider public, professional and political understandings of migration as a human condition and a world issue. Social work research about the nature of migration as outlined above-what it means, what it could mean - provides opportunities for reflection, the development of new knowledges and choices of possible alternative actions within an emerging and evolving paradigm.

\section{References}

Alaggia, R., Chau, S. and Tsang, K. T. (2001) 'Astronaut Asian families: Impact of migration on family structure form the perspective of the youth', Journal of Social Work Research and Evaluation, 2(2), pp. 295-306.

Alam, M. F. (2013) 'Bracing for and embracing difference in America's majority minority metropolis: Bangladeshi immigrant children coming of age in New York city', British Journal of Social Work, 43(4), pp. 631-50.

Alt, C. (2012) 'Familien Türkischer, Russlanddeutscher und Deutscher kinder im vergleich [Families of Turkish, Russian and German children in comparison]', in M. Krüger-Portraz and H. H Reich. (eds), Familien und Jugendpolitik in der Einwanderungsgesellschaft: Akzente, Analysen, Aktionen [Family and Youth Policy in the Immigration Society: accents, analyzes, actions], Gottingen, V\&R unipress, pp. 43-52.

Anderman, L. F. (2002) 'Cultural aspects of trauma', CPA Bulletin, August, pp. 19-21.

Bakewell, O. (2008) 'Research beyond the categories: The importance of policy irrelevant research into forced migration', Journal of Refugee Studies, 21(4), pp. 432-53.

Balibar, E. and Wallerstein, I. (1991) Race, Nation, Class: Ambiguous Identities, London, Verso.

Bastia, T. (2013) Migration and Inequality, Oxford, Routledge.

Bates, L., Baird, D., Johnson, D. J., Lee, R. E., Luster, T. and Rehagen, C. (2005) 'Sudanese refugee youth in foster care: The "lost boys" in America', Child Welfare, 84(5), pp. 631-48.

Beine, M. and Parsons, C. (2013) Climatic Factors as Determinants of International Migration, Working Paper 70, Oxford, International Migration Institute.

Bender, D., Duscha, A., Huber, L. and Klein-Zimmer, K. (eds) (2013) Transnationales Wissen und Soziale Arbeit, Weinheim/Basel, Beltz Juventa.

Benhabib, S. (2004) The Rights of Others: Aliens, Residents and Citizens, Cambridge, Cambridge University Press.

Benhabib, S., Shapiro, I. and Petranovich, D. (eds) (2007) Identities, Affiliations and Allegiances, New York, Cambridge University Press. 
Bloemraad, I. (2013) 'The promise and pitfalls of comparative research design in the study of migration', Migration Studies, 1(1), pp. 27-46.

Calhoun, C. (2000) 'Social theory and the public sphere', in B. S. Turner (ed.), The Blackwell Companion to Social Theory, 2nd edn, Oxford, Blackwell Publishers, pp. 505-44.

Castles, S. and Miller, M. J. (2009) The Age of Migration: International Population Movements in the Modern World, 4th edn, Basingstoke, Palgrave Macmillan.

Chase, E. (2010) 'Agency and silence: Young people seeking asylum alone in the UK', British Journal of Social Work, 40(7), pp. 2050-68.

Choo, H. and Sim, T. (2010) 'Health risk behaviours of foreign-born adolescents in Singapore: Exploration of risk factors in an Asian context', British Journal of Social Work, 40(7), pp. 2203-22.

Clarke, S. and Garner, S. (2005) 'Psychoanalysis, identity and asylum', Psychoanalysis, Culture and Society, 10, pp. 197-206.

Collins, P. H. (1990) Black Feminist Thought: Knowledge, Consciousness and the Politics of Empowerment, London, Routledge.

Cox, P. (2014a) 'Migration and families: Critical perspectives on social and cultural issues', in T. Geisen, T. Studer and E. Yildiz (eds), Migration, Familie und Gesellschaft: Beiträge zu Theorie, Kultur und Politik [Migration, Family and Society: Contributions of Theory, Culture and Politics], Wiesbaden, Springer VS, pp. 301-18.

Cox, P. (2014b) 'Migration, work, social work and psycho-social theories: Towards improved understandings, knowledge and practice', in T. Geisen and M. Ottersbach (eds), Work, Migration and Social Work: Processes of Migration in Modern Labouring Societies, Wiesbaden, Springer VS.

Cox, P., Geisen, T. and Green, R. (2008) 'Introduction: The importance of qualitative research to social change-preliminary considerations', in P. Cox, T. Geisen and R. Green (eds), Qualitative Research and Social Change: European Perspectives, Basingstoke, Palgrave Macmillan, pp. 1-11.

Crenshaw, K. W. (1991) 'Mapping the margins: Intersectionality, identity politics and violence against women of color', Stanford Law Review, 43(6), pp. 1241-99.

Davidson, A. (2012) The Immutable Laws of Mankind: The Struggle for Universal Human Rights, Dordrecht, Springer VS Verlag.

de Haas, H. (2008) 'The myth of invasion: The inconvenient realities of African migration to Europe', Third World Quarterly, 29(7), pp. 1305-22.

de Wet, C. (ed.) (2006) Development-Induced Displacement: Problems, Policies and People, New York and Oxford, Berghahn Books.

Dettlaff, A. J., De Haymes, M. V., Velazquez, S., Mindell, R. and Bruce, L. (2009) 'Emerging issues at the intersection of immigration and child welfare: Results from a transnational research and policy forum', Child Welfare, 88(2), pp. 47-67.

Dunkerley, D., Scourfield, J., Maegusuku-Hewett, T. and Smalley, N. (2005) 'The experiences of frontline staff working with children seeking asylum', Social Policy and Administration, 39(6), pp. 640-52.

Elliott, D. and Segal, U. A. (2012) 'Immigrant peoples and refugees', in M. Gray, J. Midgeley and S. A. Webb (eds), The SAGE Handbook of Social Work, London, Sage, pp. 564-78.

Faas, D. (2009) 'Young Turks in England and Germany: Identity formation and perceptions of Europe', in T. Küçükan and V. Güngör (eds), Turks in Europe: Culture, Identity, Integration, Amsterdam, Türkevi Research Centre, pp. 155-81.

Fals-Borda, O. and Rahman, M. A. (1991) Action and Knowledge: Breaking the Monopoly with Participatory Action Research, New York, Apex Press. 
Fouché, C., Beddoe, L., Bartley, A. and de Haan, I. (2013) 'Enduring professional dislocation: Migrant social workers' perceptions of their professional roles', British Journal of Social Work Advance Access published March 19, 2013, 10.1093/bjsw/bct054.

Geisen, T. (2004) 'People on the move: The inclusion of migrants in "labor transfer systems" - the European case', in T. Geisen, A. A. Hickey and A. Karcher (eds), Migration, Mobility and Borders, Frankfurt am Main, IKO Verlag, pp. 35-79.

Geisen, T. (2005) 'Migration als vergesellschaftsprozess [Migration as socialization]', in T. Geisen (ed.), Arbeitsmigration: WanderarbeiterInnen auf dem Weltmarkt für Arbeitskraft [Labour Migration: Migrant Workers on the World Market of Labour], Frankfurt am Main, IKO Verlag, pp. 19-36.

Geisen, T. (2010) 'Vergesellschaftung statt integration: Zur kritik des integrations-paradigmas [Socialization not integration: A critique of the integration paradigm]', in P. Mecheril, M. Dirim, S. Gomolla, X. Hornberg and K. Stojanov (eds), Spanungsverhaltnisse: Assimilationsdiskurse und interkulturell-padagogische Forschung [Stress ratios: assimilation discourses and inter-cultural-educational research], Münster, Waxmann, pp. 13-34.

Geisen, T. (2014) “"Sie wollten nur das Beste für uns!” Intergenerationale transmissionsprozesse in migrationsfamilien mit trennungserfahrungen von eltern und kindern ["They wanted only the best for us!" Intergenerational processes of transmission in migrant families with experiences of separation of parents and children]', in H. Weiss, G. Ates and P. Schnell (eds), Zwischen den Generationen: Transmissionsprozesse in Familien mit Migrationshintergrund [Between the Generations: Processes of Transmission in Families with Migrant Backgrounds], Wiesbaden, Springer VS, pp. 167-92.

Geisen, T., Studer, T. and Yildz, E. (eds) (2013) Migration, Familie und Soziale Lage: Beiträge zu Bildung, Gender und Care [Migration, Family and Social Position: Contributions of Gender, Education and Care], Wiesbaden, VS Verlag.

Geisen, T., Studer, T. and Yildz, E. (eds) (2014) Migration, Familie und Gesellschaft: Beiträge zu Theorie, Kultur und Politik [Migration, Family and Society: Contributions of Theory, Culture and Politics], Wiesbaden, VS Verlag.

Glick Schiller, N. and Wimmer, A. (2002) 'Methodological nationalism and beyond: Nation state building, migration and the social sciences', Global Network, 2(4), pp. 301-34.

Gouldner, A. (1973) For Sociology: Renewal and Critique in Sociology Today, Harmondsworth, Penguin.

Green, R. (2008) 'Bringing about social change: The role of community research', in P. Cox, T. Geisen and R. Green (eds), Qualitative Research and Social Change: European Perspectives, Basingstoke, Palgrave Macmillan, pp. 75-93.

Hamburger, F. (2009) Abschied von der Interkulturellen Pädagogik [Goodbye to Intercultural Pedagogy], Weinheim/Munchen, Juventa.

Harzig, C. and Hoerder, D. (2009) What Is Migration History?, Cambridge, Polity Press.

Hickey, A. A. (2011), 'Post-retirement migration to rural areas in the U.S.: Cultural conflict and accommodation', unpublished conference paper, Migration und Kultur Konferenz, Klagenfurt.

Hugman, R., Pittaway, E. and Bartolomei, L. (2011) 'When "do no harm" is not enough: The ethics of research with refugees and other vulnerable groups', British Journal of Social Work, 41(7), pp. 1271-87.

Humphries, B. (2008) Social Work Research for Social Justice, Basingstoke, Palgrave Macmillan. 
Huysmans, J. (2005) The Politics of Insecurity: Fear, Migration and Asylum in the EU, London, Routledge.

Ife, J. (2008) Human Rights and Social Work, Cambridge, Cambridge University Press.

International Federation of Social Workers and International Association of Schools of Social Work (IFSW and IASSW) (2013) 'Proposed international definition of social work', available online at http://ifsw.org/get-involved/global-definition-of-socialwork/.

Jacob, V. (2011) Die Bedeutung des Islam für Jugendliche aus der Türkei in Deutschland: Empfehlungen für die Soziale Arbeit in der Jugendberufshilfe [The Significance of Islam for Young People from Turkey: Recommendations for Social Work in Youth Vocational Counselling], Freiburg, Centaurus.

Kalter, F. (ed.) (2008) 'Migration und integration [Migration and integration]', Vol. Sonderhaft 48/2008, Kölner Zeitschrift für Soziologie und Sozialpsychologie [Vol. Special Issue 48/2008 Cologne Magazine of Sociology and Social Psychology], Wiesbaden, VS Verlag.

Karpf, A. (1996) The War After: Living with the Holocaust, London, Heinemann Ltd.

Kasinitz, P., Mollenkopf, J. H., Waters, M. C. and Holdaway, J. (2008) Inheriting the City: The Children of Immigrants Coming of Age, New York, Russell Sage Foundation.

Kofman, E., Kraler, A., Kohli, M. and Schmoll, A. (2011) 'Issues and debates on familyrelated migration and the migrant family: A European perspective', in A. Kraler, E. Kofman, M. Kohli and C. Schmoll (eds), Gender, Generations and the Family in International Migration, Amsterdam, Amsterdam University Press, pp. 13-54.

Leiprecht, R. (2001) Alltagrassismus: Eine Untersuchung bei Judendlichen in Deutschland und den Niederlanden [Everyday Racism: A Study of Young People in Germany and the Netherlands], Münster, Waxmann.

Lentin, A. (2008) 'Europe and the silence about race', European Journal of Social Theory, 11(4), pp. 487-503.

Leonard, P. (1997) Postmodern Welfare: Reconstructing an Emancipatory Project, London, Sage.

Liamputtong, P. (2008) 'Doing research in a cross-cultural context: Methodological and ethical challenges', in P. Liamputtong (ed.), Doing Cross-Cultural Research: Ethical and Methodological Perspectives, Dordrecht, Springer, pp. 3-20.

Liamputtong, P. (2010) 'Cross-cultural research and qualitative inquiry', Turkish Online Journal of Qualitative Inquiry, 1(1), pp. 1-14.

Maegusuku-Hewett, T., Dunkerley, D., Scourfield, J. B. and Smalley, N. (2007) 'Refugee children in Wales: Coping and adaptation in the face of adversity', Children and Society, 1(4), pp. 309-21.

Martin, S., Christie, A., Horgan, D. and O'Riordan, J. (2011) “"Often they fall through the cracks": Separated children in Ireland and the role of guardians', Child Abuse Review, 20(5), pp. 361-73.

Marvakis, A. (2011) “'No place, nowhere” for migrants' subjectivity?', in Z. Bekerman and T. Geisen (eds), International Handbook of Migration, Minorities and Education: Understanding Cultural and Social Differences in Processes of Learning, Dordrecht, Springer, pp. 67-84.

Masocha, S. (2013) 'We do the best we can: Accounting practices in social work discourses of asylum seekers', British Journal of Social Work Advance Access published March 12, 2013, 10.1093/bjsw/bcto48.

Michael, S. (2009) 'Continuities and discontinuities: Patterns of migration, adolescent immigrant girls and their family relationships', Qualitative Social Work, 8(2), pp. 229-47. 
Mohanty, C. T. (2003) Feminisms without Borders: Decolonizing Theory; Practicing Solidarity, Durham and London, Duke University Press.

Morantz, G., Rousseau, C., Bannerji, A., Martin, C. and Heymann, J. (2013) 'Resettlement challenges faced by refugee claimant families in Montreal: Lack of access to childcare', Child \& Family Social Work, 18(3), pp. 318-28.

Nguyen, T. (2005) We Are All Suspects Now: Untold Stories from Immigrant Communities after 9/11, Boston, Beacon Press.

Office for National Statistics (2011) Intergenerational Replacement and Migration in the Countries and Regions of the UK: 1971-2009, London, Office for National Statistics.

Office for National Statistics (2013) Internal Migration by Local Authorities in England and Wales, Year Ending June 2012, London, Office for National Statistics.

Okitikpi, T. and Aymer, C. (2003) 'Social work with African refugee children and their families', Child and Family Social Work, 8(3), pp. 213-22.

Page Moch, L. (1997) 'Dividing time: An analytical framework for migration', in J. Lucassen and L. Lucassen (eds), Migration, Migration History, History, Bern, Peter Lang, pp. 41-56.

Parnreiter, C. (2000) 'Theorien und forschungsansätze zu migration [Theories and research approaches to migration]', in K. Husa, C. Parnreiter and I. Stacher (eds), Internationale Migration [International Migration], Frankfurt am Main/Wien, Brandes und Apsel/Südwind [Frankfurt / Vienna, Brandes and Apsel / South], pp. 25-52.

Pearce, J. J. (2011) 'Working with trafficked children and young people: Complexities in practice', British Journal of Social Work, 41(8), pp. 1424-41.

Pitts, M. and Smith, A. (eds) (2007) Researching the Margins: Strategies for Ethical and Rigorous Research with Marginalised Communities, Basingstoke, Palgrave Macmillan.

Portes, A. and DeWind, J. (eds) (2008) Rethinking Migration: New Theoretical and Empirical Perspectives, New York and Oxford, Berghahn Books.

Portes, A. and Yiu, J. (2013) 'Entrepreneurship, transnationalism and development', Migration Studies, 1(1), pp. 75-95.

Raasch, J. (2012) 'Using history to relate: How teenagers in Germany use history to orient between nationalities', in I. Glynn and J. Kleist (eds), History, Memory and Migration: Perceptions of the Past and the Politics of Incorporation, Basingstoke, Palgrave Macmillan, pp. 68-85.

Renzaho, A., Green, J., Mellor, D. and Swinburn, B. (2010) 'Parenting, family functioning and lifestyle in a new culture: The case of African migrants in Melbourne, Victoria, Australia', Child \& Family Social Work, 16(2), pp. 228-40.

Reutlinger, C., Baghdadi, N. and Kniffki, J. (eds) (2008) Die Soziale Welt Quer Denken: TransnationalisierungundIhre Folgen für Die Soziale Arbeit [Thinking Across the Social World: Transnationalization and its consequences for social Work], Berlin, Frank und Timme [Berlin, Frank and Timme].

Riedi, A. M. and Haab, K. (2007) Jugendliche aus den Balkan: Migration und Integration als Herausforderung für die Jugendhilfe [Young People from the Balkans. Migration and Integration as a Challenge in Young People's Care], Chur, Rüeger.

Rose, N. (1998) Inventing Ourselves: Psychology, Power and Personhood, Cambridge, Cambridge University Press.

Rydgren, J. (2003) 'Mesolevel causes of racism and xenophobia', European Journal of Social Theory, 6(1), pp. 45-68.

Salomon, A. (1997) Ausgewählte Schriften: Frauenemanzipation und soziale Verantwortung [Selected Writings: Women's Emancipation and Social Responsibility], A. Feustel (ed.) (3 vols), Neuwied, Luchterhand. 
Sauer, K. E. and Held, J. (2006) 'Project: Integration of children with migrant backgrounds in Baden-Wuerttemberg and California', Social Work \& Society, 4(1), pp. 140-7.

Schaffner, D., Geisen, T. and Rein, A. (2014) Jugendliche mit Migrationshintergrund in der stationären Jugendhilfe: Eine explorative Fðllstudie [Young People with a Migration Background in the Residential Care: An Exploratory Föllstudie], Basel/Olten, Hochschule für Soziale Arbeit FHNW.

Segal, U. A. and Heck, G. (2012) 'Migration, minorities and citizenship', in K. Lyons, T. Hokenstad, M. Pawar, N. Huegler and N. Hall (eds), The SAGE Handbook of International Social Work, London, Sage, pp. 100-16.

Sirriyeh, A. (2013) 'Hosting strangers: Hospitality and family practices in fostering unaccompanied refugee children', Child \& Family Social Work, 18(1), pp. 5-14.

Spalek, B. and McDonald, L. Z. (2011) 'Editorial: Social work and political contexts: Engagement and negotiation', British Journal of Social Work, 42(6), pp. 1013-21.

Torres, L. R., Pena, J. B., Westhoff, W. W. and Zayas, L. H. (2008) 'A cross-national comparison of adolescent alcohol and drug use behaviours: US Hispanics and youth in the Dominican Republic', Journal of Drug Issues, 38(1), pp. 149-70.

Treichler, A. and Cyrus, N. (eds) (2004) Handbuch Soziale Arbeit in der Einwanderungsgesellschaft [Handbook for Social Work in the Immigration Society], Frankfurt am Main, Brandes und Apsel. [Frankfurt am Main, fire and Apsel.].

Valtonen, K. (2001) 'Social work with immigrants and refugees: Developing a participation-based framework for anti-oppressive practice: Research note', British Journal of Social Work, 31(6), pp. 955-60.

Valtonen, K. (2002) 'Social work with immigrants and refugees: Developing a participation-based framework for anti-oppressive practice. Part 2: Research note', British Journal of Social Work, 32(1), pp. 113-20.

Valtonen, K. (2008) Social Work and Migration: Immigrant and Refugee Settlement and Integration, Surrey, Ashgate.

Von Langsdorff, N. (2012) Mädchen auf ihrem Weg in die Jugendhilfe [Young Women on Their Way in Youth Care], Opladen/Berlin/Toronto, Budrich UniPress.

Wade, J., Mitchell, F. and Baylis, G. (2005) Unaccompanied Asylum Seeking Children: The Response of Social Work Services, London, British Association for Adoption and Fostering.

Warwick, I., Neville, R. and Smith, K. (2006) 'My life in Huddersfield: Supporting young asylum-seekers and refugees to record their experiences of living in Huddersfield', Social Work Education, 25(2), pp. 129-37.

Westoby, P. and Ingamells, A. (2010) 'A critically informed perspective of working with resettling refugee groups in Australia', British Journal of Social Work, 40(6), pp. 1759-76.

Williams, C. and Graham, M. (eds) (2012) Social Work in Europe: Race and Ethnic Relations, London, Sage Publications.

Williams, J. and Guémar, L. (eds) (2008) Fragments from the Dark: Women Writing Home and Self in Wales, Swansea, Hafan Books.

Wodak, R. and Van Dijk, T. (2000) Racism at the Top: Parliamentary Discourses on Ethnic Issues in Six European States, Klagenfurt, Drava.

Wright, E. O. (2010) Envisioning Real Utopias, London and New York, Verso.

Zack-Williams, T. B. (2006) 'Child soldiers in Sierra Leone and the problems of demobilisation, rehabilitation and reintegration into society: Some lessons for social workers in war-torn societies', Social Work Education, 25(2), pp. 119-28. 